\title{
PENDIDIKAN ISLAM DAN POLITIK
}

\author{
Abdul Mujib \\ IAIN Metro \\ Yuyun Yunita \\ IAIN Metro \\ abdul.mujib1082@yahoo.com
}

\begin{abstract}
Education is a fundamental part of human need which must be fulfilled by every human being. Education is part of the political problem as the management of people's affairs) based on the ideology of the state. Based on a fundamental understanding, the politics of education of a country is determined by the ideology of the country. It is this factor that determines the character and typology of the society it establishes. Thus, the politics of education can be understood as an educational strategy designed by the state in an effort to create the quality of human resources) which is aspired. Similarly with Islam; will build a society in accordance with ideological ideals. The model of society it creates will of course be different from the society formed by the State ideology system. Through this observation of the ideological characteristics, the educational system traces that take place will be easily understood. The secular-capitalist education system gave birth to a secular education strategy so that in turn it would create a typology of a secular-capitalist society. Similarly, socialism and Islamic education system.
\end{abstract}

Key Words: Education, Ideology, Politics

\begin{abstract}
Abstrak
Pendidikan merupakan bagian kebutuhan mendasar manusia yang harus dipenuhi oleh setiap manusia. Pendidikan adalah bagian dari masalah politik sebagai pengelolaan urusan rakyat) berdasarkan ideologi yang diemban negara. Berdasarkan pemahaman mendasar, politik pendidikan suatu negara sangat ditentukan oleh ideologi yang diemban negara tersebut. Faktor inilah yang menentukan karakter dan tipologi masyarakat yang dibentuknya. Dengan demikian, politik pendidikan dapat dipahami sebagai strategi pendidikan yang dirancang negara dalam upaya menciptakan kualitas sumberdaya manusia) yang dicita-citakan. Demikian dengan Islam; akan membangun masyarakat yang sesuai dengan cita-cita ideologinya. Model masyarakat yang diciptakannya tentu saja akan berbeda dengan masyarakat yang dibentuk oleh sistem ideologi Negara. Melalui pengamatan terhadap karakteristik ideologi tersebut, jejaklangkah sistem pendidikan yang berlangsung akan mudah dipahami. Sistem pendidikan sekular-kapitalis melahirkan strategi pendidikan sekular sehingga pada gilirannya akan menciptakan tipologi masyarakat sekular-kapitalis. Begitu pula sistem pendidikan sosialisme maupun Islam.
\end{abstract}

Kata Kunci: Pendidikan Idiologi, Politik

\section{Pendahuluan}

Suatu institusi keagamaan atau kemasyarakatan sepertinya sulit dipisahkan dari perkembangan situasi sosial politik yang terjadi di tengahtengah masyarakat. Sebab setting sosial politik tersebut ikut memberi warna bagi 
kelangsungan hidup suatu institusi. Hal yang sama juga berlaku bagi pranata sosial lainnya, termasuk di dalamnya pendidikan Islam (sistem dan lembaga). ${ }^{1}$

Perjalanan sejarah telah memperlihatkan berbagai rangkaian historis yang secara terus menerus ditandai dengan pergumulan antara politik dan pendidikan Islam yang terkadang memihak/menguntungkan dan tidak jarang pula justeru merugikannya.

M. Sirozi dalam bukunya Politik Pendidikan menjelaskan bahwa antara pendidikan dan politik atau sebaliknya, adalah dua elemen penting dalam sistem sosial politik di setiap negara, baik negara maju maupun negara berkembang. la sering dilihat sebagai bagian-bagian yang terpisah, tidak memiliki hubungan apa-apa, padahal kedua-duanya sating menunjang, bahu membahu dalam proses pembentukan masyarakat. ${ }^{2}$

Dalam kajian ini penulis melalui tulisan ini akan mencoba menampilkan sebuah topik dengan judul "pendidikan Islam dan politik".

Pengaruh yang dimaksud di sini adalah kebijaksanaan ${ }^{3}$ dari pemerintah dalam memberikan perhatian atau dukungan baik moril maupun materil bagi keberlangsungan pelaksanaan pendidikan Islam. Penulis melihat bahwa pembicaraan seputar masalah pendidikan Islam dan politik merupakan sesuatu yang amat luas dan panjang. ${ }^{4}$

Pendidikan dalam Islam harus kita pahami sebagai upaya mengubah manusia dengan pengetahuan tentang sikap dan perilaku yang sesuai dengan kerangka nilai/ideologi Islam. Dengan demikian, pendidikan dalam Islam merupakan proses mendekatkan manusia pada tingkat kesempurnaannya dan mengembangkan kemampuannya yang dipandu oleh ideologi/akidah Islam.

1Di dalam sejarah pendidikan Islam maupun dalam studi kependidikan, sebutan "pendidikan Islam" umumnya difahami sebatas ciri khas jenis pendidikan yang berlatar belakang keagamaan, seperti yang tertuang dalam UU No. 2 Tahun 1989 tentang SISDIKNAS. Akan tetapi Zarkawi Soeyoeti tidak sependapat, ia menyebutkan bahwa tidak hanya sekedar ciri akan tetapi ia adalah sistem pendidikan dan kelembagaannya sekaligus. Lihat : A. Malik fajar dalam M. Wahyuni Nafis, Dkk ( Tim Editor). Kontekstualisasi Ajaran Islam; 70 Tahun Prof. DR. H. Munawwir Sadzali, (Jakarta : IPHI dengan Yayasan Wakaf Paramadina, 1995), h. 507

2M. Sirozi, Politik Pendidikan, Dinamika Hubungan antara Kepentingan Kekuasaan dan Praktik Penyelenggaraon Pendidikan, (Jakarta : PT. Raja Grafindo Persada, 2005), h. 1

${ }^{3}$ Kebijaksanaan adalah keeakapan dan kemahiran bertindak dalam menghadapi sebuah persoalan. Seperti kebijaksanaan politik, artinya; kebijakan/sistem konsep resmi yang menjadi dasar prilaku politik negara. Kebijaksanaan berkaitan erat dengan pengambilan keputusan. WJS. Poerwadarminta, Kamus Umum Bahasa Indonesia, (Jakarta : Balai Pustaka, 1999), h. 740. bandingkan dengan Entang, Manajemen Kebijaksanaan Operasional (bahan Diklat ADUM). (Jakarta : LAN RI, 1999), h. 6

${ }^{4}$ Dalam sejarah Islam hubungan antara pendidikan dengan politik yang diterapkan pemerintah yang berkuasa bukanlah suatu hal yang baru, bahkan is sudah dapat dilacak sejak masa-masa pertumbuhan lembaga-lembaga pendidikan Islam semacam madrasah. Contoh paling terkenal adalah Madrasah Nizamiyah di Baghdad yang didirikan sekitar tahun 1064 oleh Wazir Dinasti Saljuk (Nizam al-Mulk). Azyumardi Azra.Pendidikan Islam; Tradisi dan Modernisasi Menuju Millenium Baru, (Jakarta : Logos Wacana Ilmu. 2000), cet. Ke-2, h. 61 
Secara pasti, tujuan pendidikan Islam adalah menciptakan SDM yang berkepribadian Islami, dalam arti, cara berpikirnya harus didasarkan pada nilainilai Islam serta berjiwa sesuai dengan ruh dan nafas Islam. Metode pendidikan dan pengajarannya juga harus dirancang untuk mencapai tujuan tersebut. Setiap metodologi yang tidak berorientasi pada tercapainya tujuan tersebut tentu akan dihindarkan. Jadi, pendidikan Islam bukan semata-mata melakukan transfer of knowledge, tetapi memperhatikan apakah ilmu pengetahuan yang diberikan itu dapat mengubah sikap atau tidak.

\section{Pembahasan}

\section{Politik terhadap pendidikan Islam di Indonesia}

Study kasus ini sangat nyata ketika pemerintah orde baru melanggengkan kekuasaanya selama 32 tahun, intervensi pemerintah melaui penyajian subjek tertentu dalam kurikulum (seperti mata pelajaran/kuliah pancasila); indoktrinasi atau penataran (seperti penataran P4), adalah bukti nyata bahwa pendidikan adalah salah satu sarana kepentingan politik penguasa.

Mochtar Buchori ${ }^{5}$ menyatakan dalam pandanganya bahwa generasi politik yang mengatur kehidupan bangsa selama periode orde baru tumbuh pada waktu kondisi pendidikan kita sudah mulai menurun. Ekspansi system pendidikan yang berlangsung sangat cepat pada waktu itu, tanpa diketehui dan dikehendaki, telah merosotkan mutu sekolahsekolah. Kemerosotan ini terjadi, karena elit pendidikan yang sangat kecil yang dimiliki saat itu, harus direntang panjang-panjang untuk memungkinkan ekspansi system yang cepat tersebut.

Pada masa Orde Baru birokrasi sebagai sarana efektif untuk melakukan intervensi kepada semua aspek kehidupan bernegara. Eksistensi penguasa concern utama bagi pemerintah, sehingga intervensi yang dilakukan oleh penguasa terhadap semua aspek kehidupan bernegara sebagai instrumen penting untuk mendorong kelestarian dan kelangsungan penguasa. Akibat dari system sentralis ini mebuat sikap apatis dikalangan cendikiawan dan semua lapisan masyarakat untuk berfikir secara demokratris, kristis, dan kreatif.

Sistem pemerintahan Orde Baru ini, menghalangi munculnya gerakan oposisi sebagai social control terhadap pemerintahan atau penguasa. Oposisi dalam suatu Negara yang demokratis menjadi suatu keharusan poltik yang harus di tempatkan pada posisi yang penting. Di Indonesia ini di gerakan oposisi di pandang oleh penguasa sebagai pendobrak terhadap eksistensi pengauasa, sehingga munculnya oposisi selalu tidak sepi oleh kecurigaan pengausa, di dukung oleh otoritarian.

5 Mochtar Buchori "Peranan Pendidikan dalam Pembentukan Budaya Politik di Indonesia", dalam Sindhunata, Menggagas Paradigma Baru Pendidikan, Yogyakarta, Kanisius, 2000, h.19 
Berbeda dengan pernyataan sebelumnya kasus yang sama terjadi dimana masih terdapatnya pemimpin kita baik dalam skala nasional maupun daerah menjadikan pendidikan (apalagi pendidikan Islam) sebagai komoditas politik, sehingga "tema-tema" pendidikan kadangladang menjadi slogan politis dalam upaya melanggengkan kekuasaanya, entah dalam kasus masih dalam pemerintahanya maupun ketika menjelang Pilkada.

Sering dilupakan oleh kalangan pendidik bahwa salah satu aspek penting dalam pendidikan Islam adalah aspek politik. Dalam aspek ini di jelaskan hubungan antara masyarakat dengan pemerintahan, hubungan antar Negara, hubungan antarorganisasi, dan sebagainya. Atas dasar ini, antara pendidikan islam dengan politik punya hubungan erat yang sulit untuk dipisahkan.

Dalam sejarah, hubungan antara pendidikan dengan politik bukanlah suatu hal yang baru. Sejak zaman Plato dan Aristoteles, para filsuf dan pemikir politik telah memberikan perhatian yang cukup intens terhadap persoalan politik. Kenyataan ini misalnya ditegaskan dengan ungkapan "As is the state, so is the school ", atau "What you want is the state, tou must put into the school ". Selain terdapat teori yang dominant dalam demokrasi yang mengasumsikan bahwa pendidikan adalah sebuah korelasi bagi suatu tatanan demokratis. ${ }^{6}$

Dalam sejarah Islam misalnya, hubungan antara pendidikan dengan politik dapat dilacak sejak masa- masa pertumbuhan paling subur dalam lembaga- lembaga pendidikan Islam. Sepanjang sejarah terdapat hubungan yang amat erat antara politik dengan pendidikan. Kenyataan ini dapat dilihat dari pendirian beberapa lembaga pendidikan Islam di Timur Tengah yang justru disponsori oleh penguasa politik. Contoh yang paling terkenal adalah madrasah Nizhamiyah di Bagdad yang didirikan sekitar 1064 oleh Wazir Dinasti Saljuk, Nizham al- Mulk. Madrasah ini terkenal dengan munculnya para pemikir besar. Misalnya, Al- Ghozali sempat mentransfer pengetahuanya di lembaga ini, yakni menjadi guru.

Di Indonesia, munculnya madrasah merupakan konsekuensi dari proses modernisasi surau yang cenderung di sebabkan oleh terjadinya tarik menarik antara system pendidikan tradisional dengan munculnya lembaga pendidikan modern dari Barat. Namun, disadari oleh Ki Hajar Dewantara bahwa peran ulama telah melahirkan system budaya kerakyatan yang bercorak kemasyarakatan dan politik, disamping spiritual. Hal ini terbukti bayangkanya para alumni pesantren yang

6James.S.Colemanditulis oleh Supriyanto dalam H. Abudin Nata, Sejarah Pertumbuhan dan Perkembangan Lembaga-lembaga Pendidikan Islam di Indonesia, Jakarta, Grasindo, 2001 
melanjutkan studi ke universitas terkemuka baik di dalammupun di luar negeri. ${ }^{7}$

Madrasah di Indonesia yang dikelola oleh suatu organisasi social kemasyarakatan banyak dipengaruhi oleh orientasi organisasinya. Madrasah yang didirikan oleh Muhammadiyah lebih bersifat ala Muhammadiyah. Demikian halnya denga madrasah yang dikelola oleh NU orientasi pendidikanya lebih menitik beratkan pada kemurnian mazhab.

Konsekuensi dari keragaman orientasi pendidikan tersebut adalah munculnya para tokoh formal dan informal yng memiliki pemikiran dan pergerakan politik yang berbeda $^{8}$, ada yang berfikir lebih modernis, fundamentalis, tradisionalis dan nasionalis. Meski prilaku politik seorang tokoh semata- mata tidak hany di tentukan oleh institusi pendidikan tertentu dan masih ada factor lain (lingkungan, sosiokultural, potensi berfikir, dan sebagainya), pengaruh suatu institusi pendidikan cukup berarti dalam membentuk karakter dan kepribadian seseorang untuk mempunyai paradigma berfikiryang berbeda.

Reformasi yang telah bergulir, semestinya dapat merintis jalan bagi pemulihan kembali demokratisasi yang selama beberapa dasawarsa mengalami diskontinuitas. Termasuk dalam hal ini adalah upaya mengembalika fungsi dan peran pendidikan sebagiamana dicita- citakan oleh para pendiri bangsa yang termaksud dalam konstitusi, yang difomulasikan dalam kalimat mencerdaskan kehidupan bangsa.

Pembenahan secara fundamental terhadap sistem pendidikan nasional merupakan conditiosine quainin yang harus dimulai dari tataran yang paling dasar visi sampai dengan implementasi dalam kurikulum. Pada tataran paling dasar, tujuan pendidikan untuk membentuk kepribadian manusia Indonesia yang tercerahkan dan memiliki tanggung jawab, merupakan substansinya. Dengan landasan visi seperti ini, maka pendidikan tidak lagi hanya ditujukan untuk memproduksi manusia terpelajar dan berkeahlian demi malayani keperluan pasar tenaga kerja manusia yang di kuasai oleh kehendak untuk mengontrol, mengekploitasi, dan berkuasa, tetapi yang di pentingkan adalah pertumbuhannya manusia berbudaya yang dapat menghayati dan memahami kehidupan bersama, sebagai komunitas mengada (the community of being) yang saling terkait satu sama lain dan karena saling menjaga dan membuahkan mengeksploitasi.

7 M. Dawam Rahardjo, Intelektual, Intelejensia Dan Perilaku Politik, Risalah Cendikiawan Muslim, Bandung, Mizan, 1993, h. 192

8Deliar Noer, Administrasi Islam di Indonesia, Yayasan Risalah, Jakarta, 1983, h. 6-7 


\section{Hubungan Pendidikan Islam dengan Penguasa}

Penguasa hal ini diidentikkan dengan pemerintah. Pemerintah adalah organisasi yang memiliki kekuasaan untuk membuat dan menerapkan hukum atau kebijakan dalam wilayah yang dikuasainya.Pada masa klasik Ulama menduduki tempat yang sangat penting dalam Islam dan dalam kehidupan kaum Muslimin. Dalam banyak hal, mereka dipandang menempati kedudukan dan otoritas keagamaan setelah Nabi Muhammad sendiri.

Salah satu hadis Nabi yang paling populer menyatakan bahwa ulama adalah pewaris para Nabi. Al'ulama' waratsah al-anbiya'. Karenanya mereka sangat dihormati kaum Muslimin lainnya, dan pendapat-pendapat mereka dianggap mengikat dalam berbagai masalah, yang bukan hanya terbatas pada masalah keagamaan saja, melainkan dalam berbagai masalah lainnya. Pentingnya ulama dalam masyarakat Islam terletak pada kenyataan bahwa mereka dipandang sebagai penafsir-penafsir legitimate dari sumber-sumber asli ajaran Islam, yakni al-Qur'an dan Hadis. Dikarenakan pengetahuan agama yang mendalam dan ketinggian akhlak, ulama bergerak pada berbagai lapisan sosial.

Mereka memiliki kekuatan dan pengaruh yang besar dalam masyarakat. Oleh karena itu juga pengetahuan termasuk pengetahuan agama yang dimiliki ulama adalah suatu kekuatan pencipta dan pembentuk; pengetahuan (knowledge) dan kekuatan (power) berkaitan erat sekali, dan konfigurasi keduanya merupakan kekuatan yang tangguh atas masyarakat. Pernyataan itu terlepas dari apakah ulama menuntut ilmu pengetahuan demi kekuatan yang dapat diterjemahkan ke dalam berbagai bidang kehidupan ataupun tidak, konsepsi masyarakat tentang tingginya nilai yang melekat pada pengetahuan agama telah memberikan dasar yang kuat bagi kontinuitas legitimasi kekuatan dan pengaruh moral ulama.

Tetapi sejarah Islam memperlihatkan bahwa kebanyakan ulama, karena alasan-alasan doktriner dan teologis, enggan menerjemahkan kekuasaan mereka secara langsung ke dalam bidang politik. Kekuatan dan pengaruh mereka lazimnya cenderung diekspresikan secara politik dan intelektual dalam bentuk keteguhan dan kewaspadaan untuk melihat bahwa penguasa dan masyarakat bertindak sesuai dengan pemahaman atau interpretasi mereka tentang Islam. Mengingat kekuatan dan pengaruh ulama, tidaklah heran kalau penguasa Muslim dari waktu ke waktu berusaha dengan berbagai cara menjinakkan dan meletakkan mereka di bawah otoritas kekuasaan Politik.

Ketika Nabi masih hidup di tengah-tengah masyarakat di Madinah ada sebagian dari warga masyarakat yang mengabdikan dirinya untuk memperdalam ilmu-ilmu agama. Di Madinah, tercatat sekelompok orang 
yang suka duduk di luar (emperan) masjid Madinah untuk menggali dan mendiskusikan pengetahuan agama yang dikenal sebgai ahl al-Shuffah. Disamping kelompok ini ada pula perseorangan yang memperdalam spesialisasi tertentu dalam bidang keagamaan dan menjadi cikal bakal lahirnya kelompok ulama di tengah-tengah masyarakat Muslim, yang baru muncul sebagai kelas tersendiri pada abad ke-9. Di samping itu, pemerintah juga berperan sebagai lembaga atau organisasi yang menyediakan dana untuk penyelenggaraan pendidikan.

\section{Hubungan Pendidikan Islam dengan Kekuasaan}

Pendidikan Islam, pada masa-masa awal, terutama masa Nabi dan sahabat, dilakukan di Masjid. Pusat-pusat Pendidikan Islam sebagaimana yang dikatakan oleh Ahmad Amin, Sejarawan Islam kontemporer, berada di Hijaz berpusat Makkah dan Madinah; Irak berpusat di Basrah dan Kufah serta Damaskus. Masing-masing daerah diwakili oleh sahabat ternama. ${ }^{5}$

Pada masa keemasan Islam, pada masa pemerintahan Abbasiyah, Pendidikan Islam di pusatkan di Baghdad, Bait al-Hikmah. Sedangkan pada pemerintahan Islam di Spanyol di pusatkan di Universitas Cordova pada pemerintahan Abdurrahman III yang bergelar Al-Dahil. Di Mesir berpusat di Universitas al-Azhar yang didirikan oleh Dinasti Fathimiyah dari kalangan Syi' ah.

Pendidikan Islam sekarang berkembang hampir di seluruh negara di dunia, baik Islam maupun yang bukan Islam. Di Indonesia studi Islam dilaksanakan di UIN, IAIN, STAIN. Ada juga sejumlah Perguruan Tinggi Swasta yang menyelengggarakan Pendidikan Islam seperti Unissula (Semarang) dan Unisba (Bandung).

Pendidikan Islam di negara-negara non Islam diselenggarakan di beberapa negara, antara lain di India, Chicago, Los Angeles, London, dan Kanada. Di Aligarch University India, Pendidikan Islam di bagi mnjadi dua: Islam sebagai doktrin di kaji di Fakultas Ushuluddin yang mempunyai dua jurusan, yaitu Jurusan Madzhab Ahli Sunnah dan Jurusan Madzhab Syi'ah. Sedangkan Islam dari Aspek sejarah di kaji di Fakultas Humaniora dalam jurusan Islamic Studies. Di Jami'ah Millia Islamia, New Delhi, Islamic Studies Program di kaji di Fakultas Humaniora yang membawahi juga Arabic Studies, Persian Studies, dan Political Science.

Di Chicago, Kajian Islam diselenggarakan di Chicago University. Secara organisatoris,Pendidikan Islam berada di bawah Pusat Studi Timur Tengah dan Jurusan Bahasa, dan Kebudayaan Timur Dekat. Dilembaga ini, kajian Islam lebih mengutamakan kajian tentang

\footnotetext{
${ }^{5}$ Ahmad Amin, Dhuha al-Islam, Mesir: Dar al-Kutub al-Ilmiyyah, Tt. Tc., h. 86
} 
pemikiran Islam, Bahasa Arab, naskah-naskah klasik, dan bahasa-bahasa non-Arab.

Di Amerika, studi Islam pada umumnya mengutamakan studi sejarah Islam, bahasa-bahasa Islam selain bahasa Arab, sastra dan ilmuilmu social. Studi Islam di Amirika berada di bawah naungan Pusat Studi Timur Tengah dan Timur Dekat.

Di UCLA, Pendidikan Islam dibagi menjadi empat komponen. Pertama, doktrin dan sejarah Islam; kedua, bahasa Arab; ketiga, ilmuilmu social, sejarah, dan sosiologi. Di London, Pendidikan Islam digabungkan dalam School of Oriental and African Studies (Fakultas Studi Ketimuran dan Afrika) yang memiliki berbagai jurusan bahasa dan kebudayaan di Asia dan Afrika. ${ }^{6}$

Dengan demikian obyek Pendidikan Islam dapat dikelompokkan menjadi beberapa bagian, yaitu, sumber-sumber Islam, doktrin Islam, ritual dan institusi Islam, Sejarah Islam, aliran dan pemikiran tokoh, studi kawasan, dan bahasa.

Di Indonesia kebijaksanaan politik pemerintah serta pengaruhnya tehadap perkembangan pendidikan Islam melalui empat periode perkembangan politik (Pra kemerdekaan, orde lama, orde baru dan orde reformasi). kebijaksanaan politik penguasa pada zamannya jelas telah berpengaruh secara signifikan terhadap perkembangan pendidikan Islam baik langsung maupun tidak langsung.

Dalam bidang pendidikan Islam, pengaruh yang ditimbulkan oleh kebijaksanaan politik pemerintah adakalanya bersifat positif konstruktif walaupun belum 100\% memuaskan namun tidak jarang juga yang negatif destruktif, seperti pada zaman pra kemerdekaan. Kebijakan pemerintah Belanda pada zaman pra kemerdekaan sangat kental dengan sikap "diskriminasi" dengan kebijakan "ordonansi guru dan ordonansi sekolah liar", Jepang agak lunak dan terkesan akomodatif persuasif walaupun semua itu hanya demi kepentingan politis semata-mata.

Pada periode berikutnya, yaitu orde lama sebuah harapan baru muncul ke tengah-tengah dunia pendidikan Islam dengan berdirinya Departemen Agama pada tanggal 3 Januari 1946 melalui usulan Komite Nasional Indonesia Pusat (KNIP) tertanggal 11 November 1945. Pendidikan Islam mulai mendapat angin segar dengan terbitnya beberapa kebijakan pemerintah melalui Depag yang terkait langsung dengan pendidikan Islam. 
Pada era orde baru dikenal sebuah kebijakan yang cukup berpengaruh dan masih akrab ditelinga umat Islam sampai saat ini apalagi para pengelolapendidikan Islam, yaitu Surat Keputusan Bersama (SKB) tiga menteri (Menteri Agama, Menteri Pendidikan dan Kebudayaan, Menteri Dalam Negeri) tahun 1975, No. 06/1975, 037/U/1975 dan 36/1975 tentang peningkatan mutu pendidikan Islam pada madrasah. Serta sebuah undang-undang tentang SISDIKNAS yaitu UU No. 2 Tahun 1989.

Akhirnya pada era reformasi setelah kejayaan orde baru ditumbangkan oleh gerakan reformasi 1998 dan munculnya berbagai tuntutan perobahan disegala bidang kehidupan, termasuk pendidikan Islam, maka diberlakukanlah Undang-Undang Nomor 20 tahun 2003 tentang SISDIKNAS yang memberi pengaruh cukup signifikan terhadap perkembangan pendidikan Islam di Indonesia.

\section{Tujuan Pendidikan Islam}

Tujuan pendidikan dalam Islam adalah upaya sadar, terstruktur, terprogram, dan sistematis dalam rangka membentuk manusia yang memiliki:

\section{Kepribadian Islam}

Tujuan ini merupakan konsekuensi keimanan seorang Muslim, yaitu keteguhan dalam memegang identitas kemuslimannya dalam pergaulan sehari-hari. Identitas itu tampak pada dua aspek yang fundamental, yaitu pola pikir ('aqliyah) dan pola sikap (nafsiyah) yang berpijak pada akidah Islam. Paling tidak, terdapat tiga langkah untuk membentuk kepribadian Islam sebagaimana yang dicontohkan Rasulullah SAW., yaitu: Pertama, Menanamkan akidah Islam sebagai sebagai 'aqîdah 'aqliyah-akidah yang muncul dari proses pemikiran yang mendalam - kepada setiap orang.

Kedua, Menanamkan sikap konsisten dan istiqamah kepada setiap orang agar cara berpikir dan kecenderungan insaninya tetap berada di atas pondasi akidah yang diyakininya. Ketiga, Mengembangkan kepribadian dengan senantiasa mengajak setiap orang bersungguhsungguh dalam mengisi pemikirannya dengan tsaqâfah Islâmiyah dan mengamalkan perbuatan yang selalu berorientasi pada ketaatan kepada Allah SWT.

\section{Menguasai tsaqâfah islâmiyah dengan handal.}

Islam mendorong setiap Muslim untuk menjadi manusia yang berilmu dengan cara mewajibkannya untuk menuntut ilmu. Berdasarkan takaran kewajibannya, menurut al-Ghazali, ilmu dibagi ke dalam dua kategori, yaitu: (1) ilmu yang fardlu 'ain, yaitu wajib dipelajari setiap Muslim seperti: ilmu-ilmu tsaqâfah Islam yang terdiri konsepsi, ide, dan hukum-hukum Islam (figh), bahasa Arab, sirah Nabi, Ulumul Quran, 
tahfidz al-Quran, Ulumul Hadits, ushul fikih, dll; (2) ilmu yang dikategorikan fardhu kifayah, biasanya ilmu-ilmu yang mencakup sains dan teknologi serta ilmu terapan-keterampilan seperti biologi, fisika, kedokteran, pertanian, teknik, dll.

3. Menguasai ilmu terapan (pengetahuan, ilmu, dan teknologi/PITEK).

Menguasai PITEK diperlukan agar umat Islam mampu mencapai kemajuan material sehingga dapat menjalankan fungsinya sebagai khalifatullah di muka bumi dengan baik. Islam menetapkan penguasaan sains sebagai fardhu kifayah, yaitu kewajiban yang harus dikerjakan oleh sebagian Muslim apabila ilmu-ilmu tersebut sangat diperlukan umat seperti kedokteran, kimi, fisika, industri penerbangan, biologi, teknik, dll. Pada hakikatnya ilmu pengetahuan terdiri atas dua hal, yaitu: (1) pengetahuan yang mengembangkan akal manusia sehingga ia dapat menentukan suatu tindakan tertentu; (2) pengetahuan mengenai perbuatan itu sendiri.

Allah SWT. telah memuliakan manusia dengan akalnya. Allah menurunkan al-Quran dan mengutus Rasul-Nya dengan membawa Islam agar beliau menuntun akal manusia dan membimbingnya ke jalan yang benar. Pada sisi yang lain, Islam memicu akal untuk dapat menguasai PITEK karena dorongan dan perintah untuk maju merupakan buah dari keimanan. Dalam kitab Fath al-Kabîr, juz III, misalnya, diketahui bahwa Rasulullah saw. pernah mengutus dua orang sahabatnya ke negeri Yaman untuk mempelajari pembuatan senjata muktahir, terutama alat perang yang bernama dabbabah, sejenis tank yang terdiri atas kayu tebal berlapis kulit dan tersusun dari roda-roda. Rasulullah saw. memahami manfaat alat ini bagi peperangan melawan musuh dan menghancurkan benteng lawan.

4. Memiliki keterampilan yang tepat guna dan berdayaguna.

Penguasaan keterampilan yang serba material ini merupakan tuntutan yang harus dilakukan umat Islam dalam rangka pelaksanaan amanah Allah Swt. Hal ini diindikasikan dengan terdapatnya banyak nash yang mengisyaratkan setiap Muslim untuk mempelajari ilmu pengetahuan umum dan keterampilan. Hal ini dihukumi sebagai fardhu kifayah.

\section{Kesimpulan}

Pendidikan Islam adalah sebuah disiplin yang sangat tua seumur dengan kemunculan Islam sendiri. Pengkajian Islam dalam sejarah panjangnya mewujud dalam berbagai tipe dan menyediakan lahan yang sangat kaya bagi kegelisahan akademik dari kalangan insider maupun outsider. Jika Studi outsider terwadahi dalam bentuk Orientalisme atau Islamologi, maka kajian insider memunculkan model ngaji yang berorientasi pengamalan, apologis yang memberi counter 
terhadap orientalisme, Islamisasi ilmu yang berupaya memberikan landasan paradigma Islam bagi ilmu-ilmu sekuler atau studi Islam klasik yang bersifat kritis namun masih berorientasi pada pengamalan. Sebagai objek studi, Islam harus didekati dari berbagai aspeknya dengan menggunakan multidisiplin ilmu pengetahuan untuk mengurai fenomena agama ini. Salah satunya adalah melalui pendekatan sejarah yang tidak dapat diabaikan begitu saja bagi seseorang yang ingin memahami tentang Islam dengan benar.

\section{Referensi}

Abdullah, M. Amin, Studi Agama Normativitas atau Historisitas, Yogyakarta;1996 Abdullah, Taufik dan M Rusli Karim, (ed.), Metodologi Penelitian Agama Sebuah Pengantar, Yogyakarta; Tiara Wacana Yogyakarta, 1990

Abdullah, Taufik, (ed.), Sejarah dan Masyarakat, Jakarta; Pustaka Firdaus, 1987

Amin, Ahmad, Dhuha al-Islam, Mesir: Dar al-Kutub al-Ilmiyyah, tt

Babbie, Earl, The Practice of Social Research, California: Wadasworth Publishing Co., 1986

Deliar Noer, Administrasi Islam di Indonesia, Yayasan Risalah, Jakarta, 1983,

Hakim, Atang Abdul, dan Jaih Mubarok, Metodologi Studi Islam, (Bandung: Rosda).

James.S.Colemanditulis oleh Supriyanto dalam H. Abudin Nata, Sejarah Pertumbuhan dan Perkembangan Lembaga-lembaga Pendidikan Islam di Indonesia, Jakarta, Grasindo, 2001

M. Dawam Rahardjo, Intelektual, Intelejensia Dan Perilaku Politik, Risalah Cendikiawan Muslim, Bandung, Mizan, 1993,

Mochtar Buchori "Peranan Pendidikan dalam Pembentukan Budaya Politik di Indonesia", dalam Sindhunata, Menggagas Paradigma Baru Pendidikan, Yogyakarta, Kanisius, 2000, h.19

Nata, Abudin Nata, Metodologi Studi Islam, Jakarta: PT. Raja Grafindo Persada, 1998

Praja, Juhaya S., Filsafat dan Metodologi Ilmu dalam Islam dan Penerapannya di Indonesia, Jakarta: Teraju, 2002

Sayyed Husen Nasr, Menjelajah Dunia Modern, (terj.) Hasti Tarekat, dari judul asli A Young Muslim's Guide in The Modern World, Bandung: Mizan, 1995

Sumardi, Mulyanto, (ed.), Penelitian Agama, Jakarta: Sinar Harapan, 1982 